\title{
EVIDENCE FOR PREHISTORIC EARTHQUAKES ON THE SUPERSTITION HILLS FAULT FROM OFFSET GEOMORPHIC FEATURES
}

\author{
By Scott C. Lindvall, ${ }^{*}$ Thomas K. Rockwell, and \\ Kenneth W. Hudnut
}

\begin{abstract}
Offset geomorphic features along the Superstition Hills fault show evidence for at least one slip event prior to the 1987 surface rupture, and possibly as many as four to five earlier prehistoric earthquakes. We documented several geomorphic features that appeared offset by multiple events by making detailed topographic maps. Offset features were abundant along reaches of the fault with high topographic relief and large displacement. Slip distribution for the penultimate event, as recorded by offset rills, streams, and shrub-coppice dunes, is very similar to the slip distribution from the 1987 earthquake through April 1988. This similarity may prove to be fortuitous if afterslip from the 1987 event continues to increase the total slip for this earthquake. But if afterslip associated with the 1987 event ceases in the near future, then the past two earthquakes were nearly identical in slip, and the Superstition Hills fault may be expected to produce characteristic earthquakes of roughly magnitude $6 \frac{1}{2}$.
\end{abstract}

\section{INTRODUCTION}

Paleoseismic studies of strike-slip faults have utilized offset streams and other features to determine the slip per event, length of rupture, and magnitude of prehistoric earthquakes (Wallace, 1968; Sieh, 1978; Sieh and Jahns, 1984; Rockwell and Pinault, 1986; Zhang et al., 1987). Tectonically offset geomorphic features have enabled these and other workers to characterize a particular fault's prehistoric activity and assess its future seismic potential. Sieh (1978) measured stream offsets to show the slip distribution for the $1857 M>8$ earthquake on the San Andreas fault in south-central California. Rockwell and Pinault (1986), grouping offsets of similar amounts, determined the slip per event and estimated the magnitudes of prehistoric earthquakes on a segment of the Elsinore fault in the Coyote Mountains of southern California.

The Superstition Hills fault ruptured in the 24 November 1987 Superstition Hills earthquake $\left(M_{s}=6.6\right)$ (Sharp et al., 1989). Displacements from the 1987 earthquake, as well as apparent offsets that appear to represent prehistoric slip events, have been recorded by offset rills, streams, and shrub-coppice dunes (mounds of aeolian sand accumulated at the base of a bush) along the Superstition Hills fault. Surface rupture from the November 1987 earthquake provided calibration for studying slip from past events, using offset geomorphic features.

The concept of similar amounts of slip per event or "characteristic" earthquakes was first implied by Wallace (1970) when he presented the idea of average recurrence intervals. The quotient of slip per event and the long-term slip rate, or recurrence interval, assumes that slip in an earthquake will be repeated by a similar amount in future events. Schwartz and Coppersmith (1984) have shown that some individual faults and fault segments produce repeated similar size earthquakes. Their charac-

\footnotetext{
* Present Address: Lindvall, Richter \& Associates, 825 Colorado Blvd., Los Angeles, California 90041.
} 
teristic earthquake model proposes that repeating or successive earthquakes have a narrow range of magnitudes at or near the maximum possible for any given fault, and is supported by several geologic observations. On the south-central San Andreas fault, displacement that occurred during the 1857 earthquake is approximately equal to the two previous events at Wallace Creek (Sieh and Jahns, 1984) and other localities.

This paper presents the results of our topographic mapping and analysis of offset geomorphic features along the Superstition Hills fault, and the implications regarding the characteristic earthquake model.

\section{The Superstition Hills Earthquake Sequence and Regional Tectonics}

The 24 November 1987 Superstition Hills earthquake sequence produced surface rupture along northeast-trending cross faults and the northwest-trending Superstition Hills fault (Hudnut et al., 1989; Sharp et al., 1989). On 24 November a $M_{s}=$ 6.2 earthquake ruptured the northeast-trending, left-lateral Elmore Ranch fault oriented nearly perpendicular to the right-lateral Superstition Hills fault. This event apparently triggered the larger $M_{s}=6.6$ event on the Superstition Hills fault approximately $12 \mathrm{hrs}$ later (Hudnut et al., 1989), which ruptured along its entire $23.5 \mathrm{~km}$ mapped length, as well as a several $\mathrm{km}$ long, previously unknown southern extension (Sharp et al., 1989). Co-seismic slip and associated afterslip (through April 1988) from the larger earthquake produced a maximum total displacement of about $80 \mathrm{~cm}$ on the Superstition Hills fault.

The Superstition Hills fault is part of the seismically active San Jacinto fault zone of southern California (Fig. 1). As the Clark fault strand of the San Jacinto fault zone enters the western margin of the Salton trough, the zone splays into individual segments: the Coyote Creek fault, the San Felipe Hills fault, the Superstition Mountain fault, and the Superstition Hills fault. Farther to the southeast lies the Imperial fault, which trends more northerly than the San Jacinto fault zone. The San Andreas fault zone runs along the northeast margin of the Salton Sea. The seismically active Salton trough forms the transition region from the dextral strike-slip tectonics of the San Andreas fault system to the spreading regime of the East Pacific Rise in the Gulf of California.

The Superstition Hills is an uplifted area of relatively low relief comprised of a highly deformed section of the Plio-pleistocene Brawley Formation lacustrine sediments. The Superstition Hills fault extends from near the northwest end of the hills approximately $24 \mathrm{~km}$ southeast to where it marks the southern margin of the Superstition Hills uplift. Moderate-sized earthquakes in the Salton trough region have triggered surface slip on the Superstition Hills fault in the 1968 Borrego Mountain earthquake (Allen et al., 1972), the 1979 Imperial Valley earthquake (Fuis, 1982), and the 1981 Westmorland earthquake (Sharp et al., 1986). These three triggered slip events have cumulatively produced a maximum of nearly $4 \mathrm{~cm}$ of dextral slip on parts of the Superstition Hills fault (Sharp et al., 1986).

\section{GeomorPhic Features}

The sparsely vegetated Superstition Hills are subject to a hyper-arid climate and receive an average of less than $6 \mathrm{~cm}$ of rain annually (Waters, 1983; Clark, 1972) from thunderstorm activity. The soft and easily erodible Brawley Formation produces badland-type topography in areas of moderate to high relief within the hills. This locally dissected and deeply incised topography provides excellent geomorphic markers to record slip along the fault (Figs. 2 and 3). The low precipitation in this 


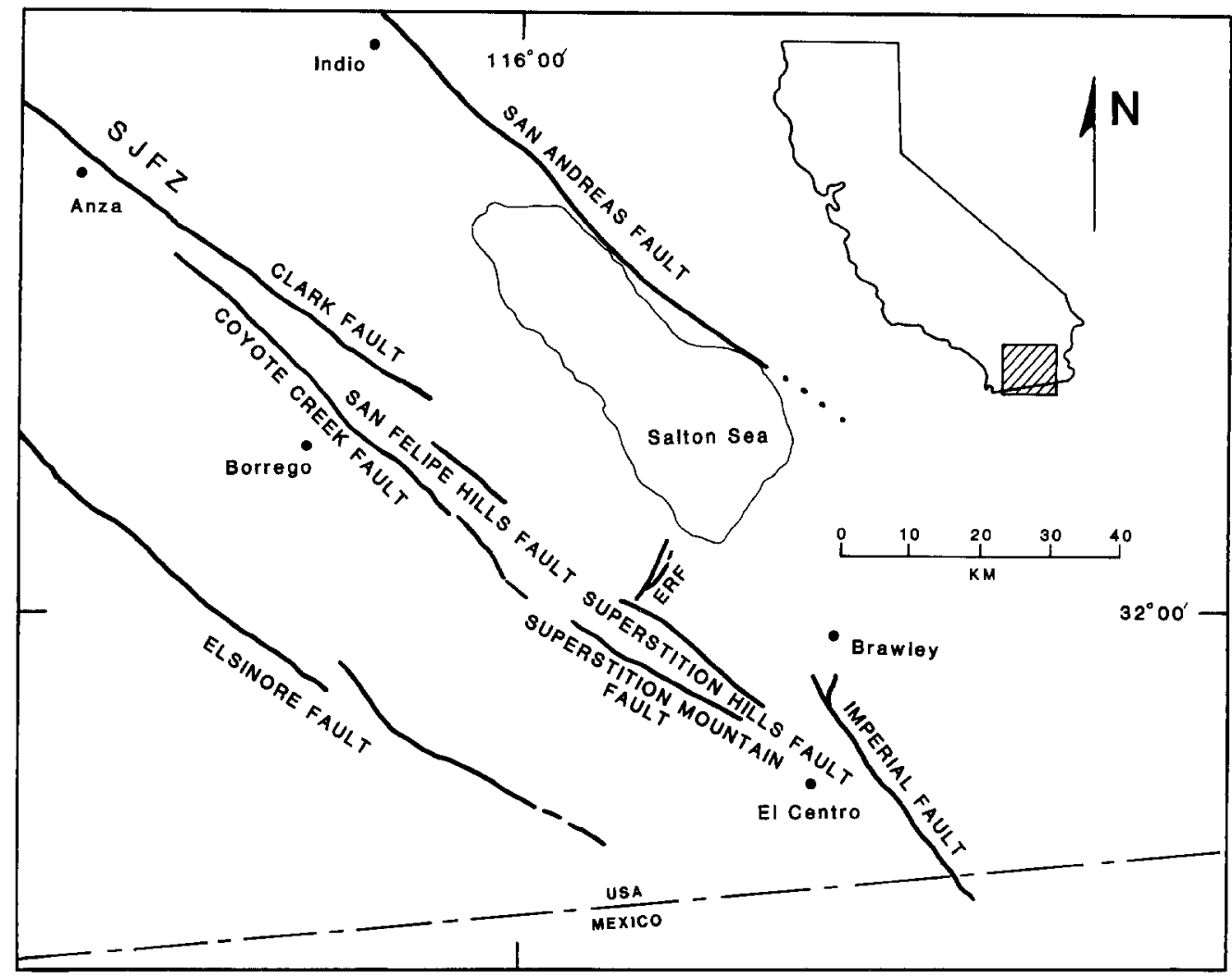

FIG. 1. Index map showing major faults of the Salton trough region. The highly segmented San Jacinto fault zone (SJFZ) consists of the Clark, Coyote Creek, San Felipe Hills, Superstition Mountain, and Superstition Hills faults. The Elmore Ranch fault (ERF) and the Superstition Hills fault ruptured in the 24 November 1987 earthquake sequence.

area has apparently enabled some of the geomorphic features to be preserved for hundreds of years.

A total of 38 offset geomorphic features, which express evidence of having been offset prior to the 1987 earthquake, were observed along the Superstition Hills fault. The offset geomorphic features that provided paleoslip data are rills, ephemeral streams, shrub-coppice dunes, and terrace risers. Fluvial features ranged in size from small rills with microdrainage basins of less than 2 square meters to small stream channels that drain basins in excess of hundreds of square meters. The channels in this region only carry water during and immediately following precipitation.

\section{Data ACQUisition AND Methods}

\section{Field Measurements}

The majority of data collection for this study was conducted between the middle of March and the early part of May 1988. During this time, the $23.5 \mathrm{~km}$ length of the northern and central segments of the fault was traversed, with most portions of the fault examined two or more times. The southern segment (Sharp et al., 1989) was not included in this study because displacements were small and the entire length of the segment lies topographically below the shoreline of ancient Lake Cahuilla. Further, most of the rupture along this segment occurred in tilled fields and, hence, older geomorphic features have been destroyed by plowing. Each offset 


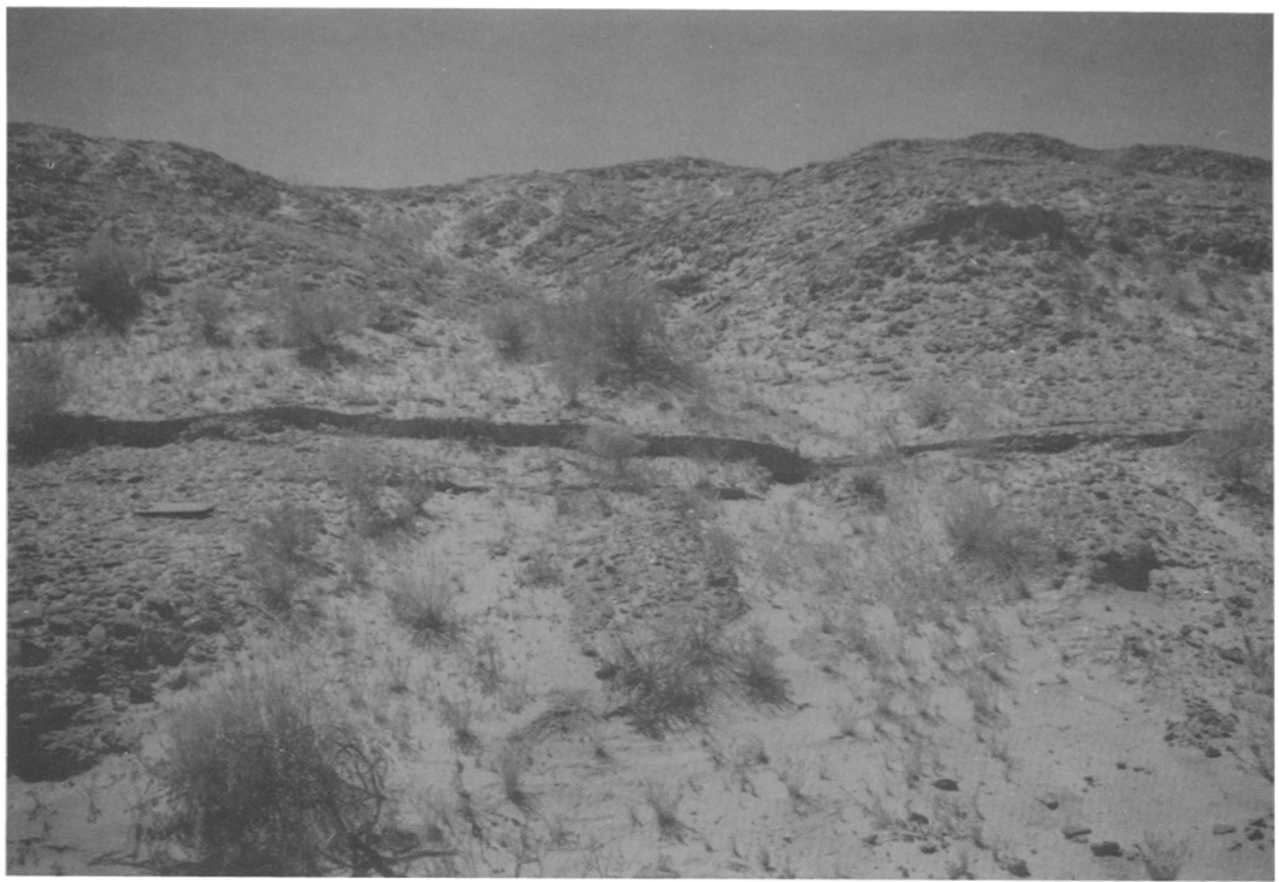

FIG. 2. Small beheaded stream channel at site 7 . The beheaded channel on the left is offset $200 \pm 30$ $\mathrm{cm}$ from the active channel upstream from the fault. The channel on the right was offset $68 \pm 5 \mathrm{~cm}$ in the 1987 earthquake. Clipboard in left center of photo for scale. See Figure 11 for contour map of this site.

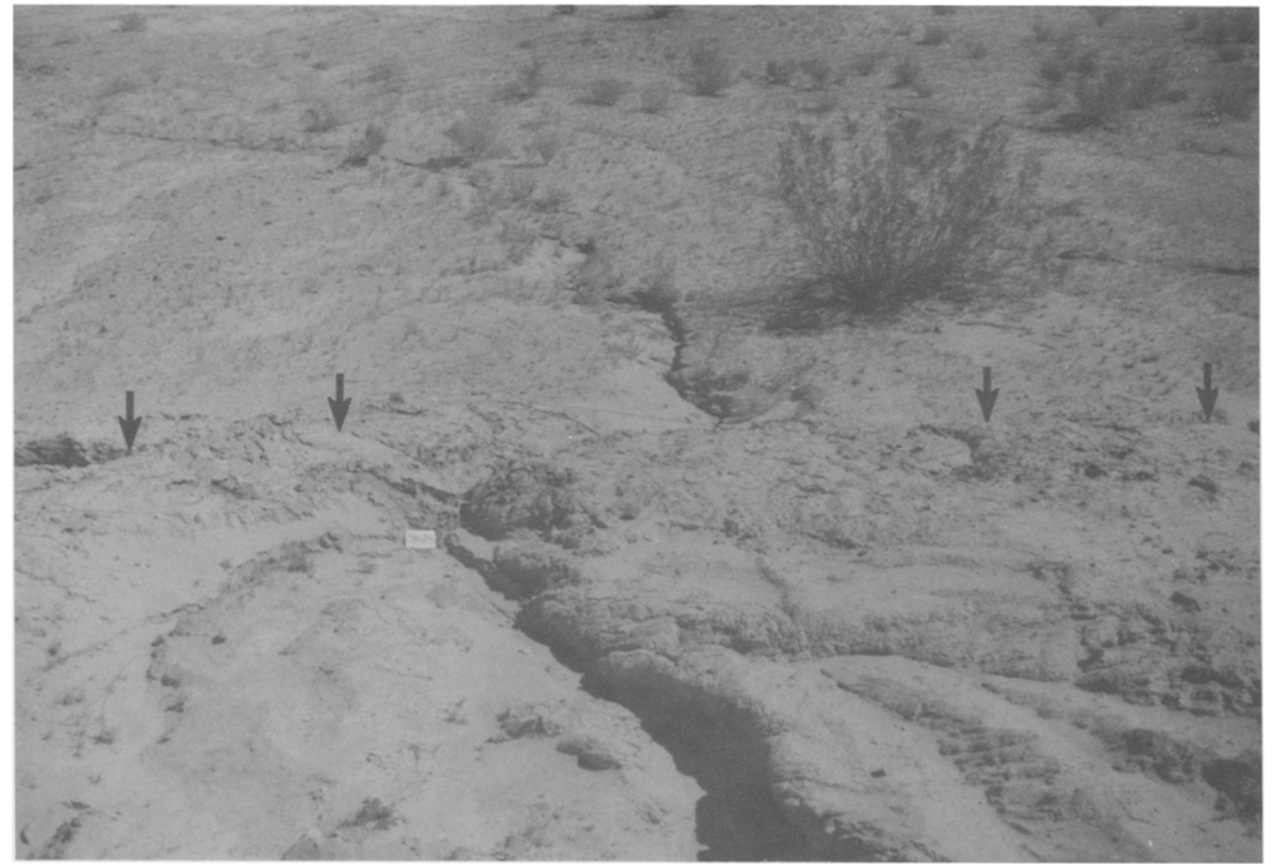

FIG. 3. Downstream view of the incised rill offset $146 \pm 20 \mathrm{~cm}$ at site $24 \mathrm{a}$. The 1987 rupture consists of a single strand through the center of the photo. The fault trace (denoted by arrows) is not readily seen in the photo since the scarp in the thick clay gouge zone degraded rapidly. White 3 by 5 inch card in the rill upstream from the fault for scale. See Figure 6 for contour map of this site. 
was measured and documented by at least two of the co-authors, thus enabling valuable discussions and scrutiny and greatly reducing possible bias in the data collection.

In the field, sites of apparent multiple offsets and sites of 1987 slip measurement were located on postearthquake USGS aerial photographs (1:8000 scale) on which the November 1987 surface rupture was clearly visible. These locations were later transferred to the Kane Spring, Superstition Mountain, and Brawley NW $7.5 \mathrm{~min}$ topographic quadrangles (Fig. 4). Using a metric steel tape, offsets were measured by matching similar features such as channel centers or channel walls that were nearly perpendicular to and intersected the fault.

On channels that were rounded or otherwise lacking distinct piercing points, linear features of the channel morphology were projected to the fault and the offset was measured, as with all other features, along strike of the fault. This technique is used to restore the channel wall or center feature to its original configuration prior to subsequent rounding and was used for determining displacement at several sites.

Each offset was assigned a measurement error, and the quality of each measurement was rated as excellent, good, fair, or poor. An excellent offset is well preserved, prominent, and unambiguous, whereas an offset designated as poor may be poorly preserved, subtle, or yield ambiguous measurements and interpretations. Many poor quality apparent offsets, that could have been produced by other processes, were not included in this study. For instance, we commonly found but did not use rills that were deflected around plants or shrub-coppice dunes at the fault and channels that had been significantly altered during the postearthquake rains.

In addition to measuring large offsets that appear to have been produced during previous earthquakes, the slip distribution of the November 1987 rupture was developed from measurements collected at 100 points along the length of the northern and central segments of the Superstition Hills fault. The purpose of quantifying the recent rupture during the 8 week period from March to May 1988
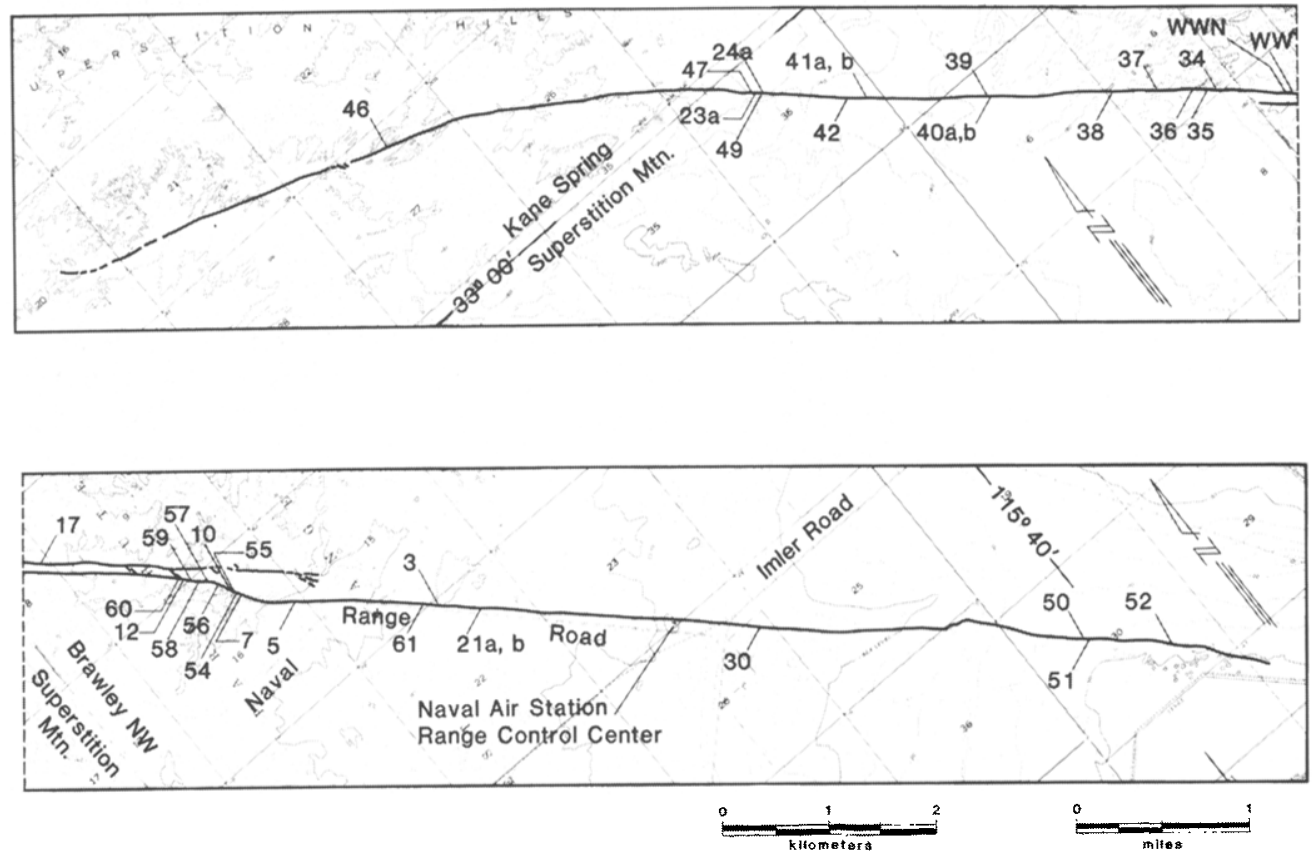

FIG. 4. Site locations of geomorphic features offset by multiple events along the 1987 Superstition Hills fault rupture. Trace of rupture modified from Kahle et al. (1988). 
was to compile a data set that included co-seismic slip and afterslip for comparison with sites of apparent multiple offsets. Other studies of the November 1987 rupture (Williams and Magistrale, 1989; Sharp et al., 1989) are presumably more detailed in scope and have better documented the slip in the areas of low displacements (at the ends of the fault and throughout the fault step-over). This is because small 1987 offsets, typically less than $15 \mathrm{~cm}$, have been masked or significantly altered by water and wind during the period between November 1987 and March 1988. Most features that were used as piercing points to determine slip in the 1987 earthquake are the same type used to determine prehistoric slip such as rills, gullies, streams, and shrub-coppice dunes. Displaced road berms, tire tracks, and grass lines were also used to produce the 1987 slip distribution, but these constitute only about 5 per cent of the data.

\section{Contour Maps}

Detailed topographic maps were produced of selected sites with apparent multiple offsets using two related methods similar to plane table mapping. The sites chosen for detailed documentation were all of good to excellent quality, with most of the 1987 displacement along one or two discrete strands of the fault. Because most features were small and total offsets less than $3 \mathrm{~m}$, accuracy and detail was a primary concern. Therefore, all maps were made using a theodolite mounted with an electro-optical distance measurer. The method used to construct contour maps of sites 23a, 24a, 39, WW, and 21 utilized a Zeiss Elta 4 surveying instrument, a Hewlett-Packard-41 calculator/data collector, and a standard single pen plotter. First the instrument was set up and a baseline and its azimuth established. Then between approximately 70 and 130 data points were shot using a rod-mounted reflector at each site. The data collector converted all distances and angles into $\mathrm{XYZ}$ coordinates and stored the data. Information from the data collector was downloaded and backed up on a laptop computer in the field before creating a plot of data points and elevations with the battery-driven plotter. The resulting plot of point locations and elevations was used as a base map for drawing the contours by hand.

Using the second method, maps of sites 38 and 7 were generated using a contouring program, after the distance and angle measurements were converted to XYZ coordinates with instrument-specific software. A WILD TC-2000 surveying instrument and a GRE-3 data collector were used to gather field data. Site 42 was not computer-generated, but rather hand-contoured using a plot of point locations and elevations. This was because the site's very low relief was difficult for the computer to depict. At sites where the WILD TC-2000 was used, the intent was to generate the maps by computer, and therefore between 170 (Site 38) and 290 (Site 7) data points were collected for each site. We felt more topographic control was necessary for the computer-generated plots than the maps contoured by hand in the field.

\section{OBSERVATIONS OF 1987 AND EARLIER OFFSETS}

Data representing total of fset of geomorphic features collected for this study are listed in Table 1. In general, the larger offsets correspond with the larger and more pronounced, and hence presumably older, rills and gullies along the fault. The smaller offsets are associated with smaller and presumably younger geomorphic features. The majority (over 70 per cent) of the dextral offsets fall between 100 and $200 \mathrm{~cm}$. Spatially, most of the data are distributed between 6 and $16 \mathrm{~km}$ from the northwest terminus of the fault.

The smallest offsets, 31 and $50 \mathrm{~cm}$, were found near the ends of the fault where 
TARLE. 1. Neasurements of Offet Geomorphic Features Along the superstition Hills Faul

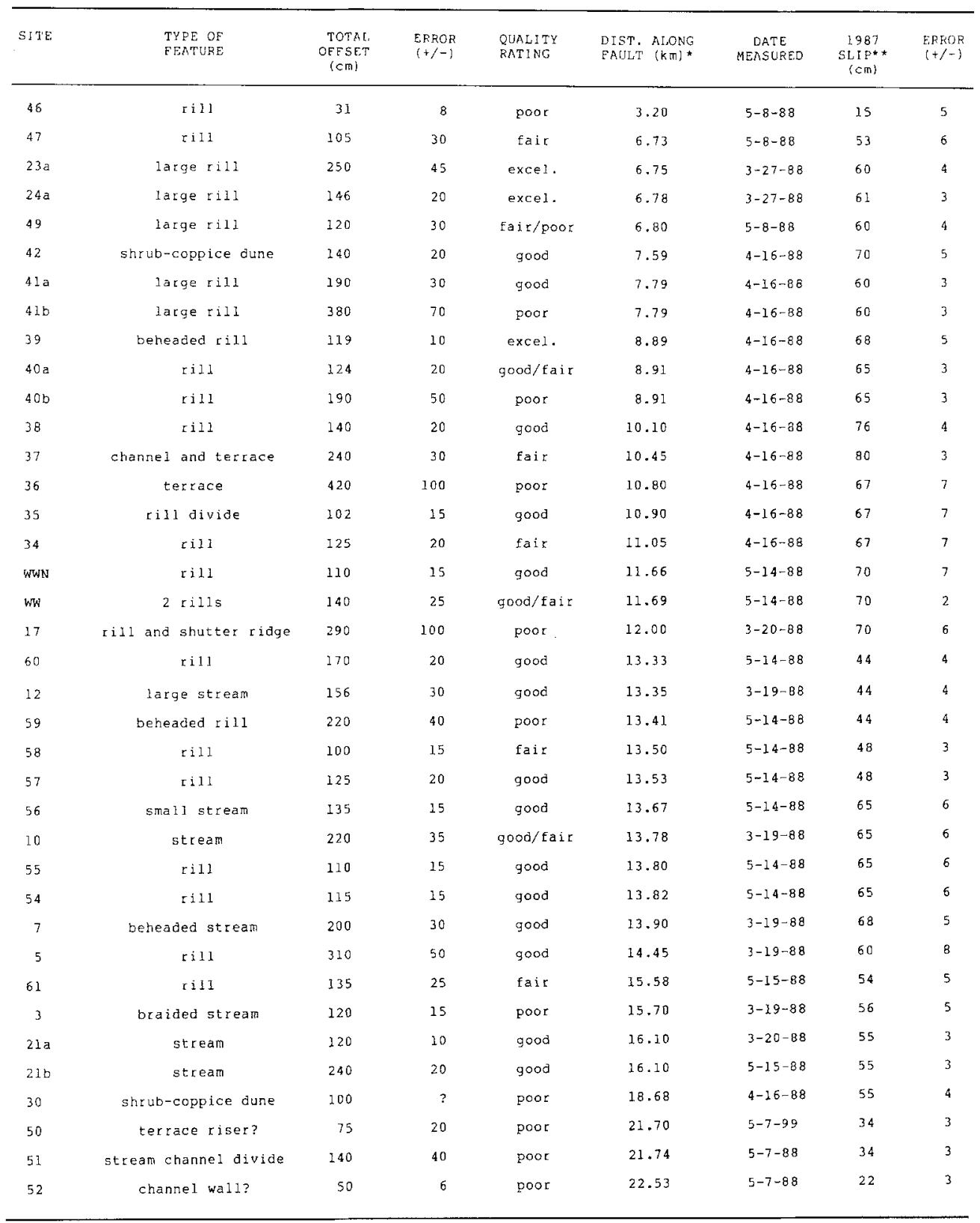

* Erom NW end

* Values represent 1987 slip (through April 1988) measured nearest to site.

slip dies out significantly. The largest offsets measured were 380 and $420 \mathrm{~cm}$ and are located along the reach of the fault that experienced the greatest amount of displacement in the 1987 event. The quality of both of these large offsets, however, was judged as poor. The lack of good quality, large $(>350 \mathrm{~cm})$ offsets may be a result of the degradation of these presumably old features with time. Few and poor quality data at the ends of the fault probably reflect the difficulty with which smaller magnitude offsets are preserved.

Two other factors that significantly influence the distribution of our data are 
topography and the position of the $300 \mathrm{yr}$ old Lake Cahuilla shoreline. Slopes traversed by the fault contain a large number of the offset features because they produce the linear, incised gullies that remain captured or contained between the channel's walls through time. Stream channels on the flat desert floor generally exhibit a high sinuosity, poorly defined channel walls, and little or no incision. This lack of distinct channel morphology may be one reason that slip was poorly preserved from events before 1987 in areas of low topographic relief. A more important factor is that areas of low relief only contain a few rills and gullies, and thus provide only a limited number of geomorphic features to record tectonic offset. Fault geometry, in some areas, is responsible for relief along the trace and is best illustrated approximately $4 \mathrm{~km}$ northwest of the Naval Air Station Range Control Center, where the fault makes a bend and step (Fig. 4).

The reach of the Superstition Hills fault southeast from Imler Road was repeatedly inundated by the waters of Lake Cahuilla over the past millennium (Sieh, 1987; Waters, 1983). It seems unlikely that very old offsets would be preserved along this part of the fault and, hence, we suspect the $140 \mathrm{~cm}$ offset at site 51 (judged as poor) may not represent a tectonic offset. Only the slip event prior to 1987 occurred after the lake receded (Hudnut and Sieh, 1989), enabling rupture from the penultimate event to be recorded in the present geomorphic regime. Of the 38 multiple offsets presented in Table 1, we studied several in detail, and documentation of eight of these sites follows.

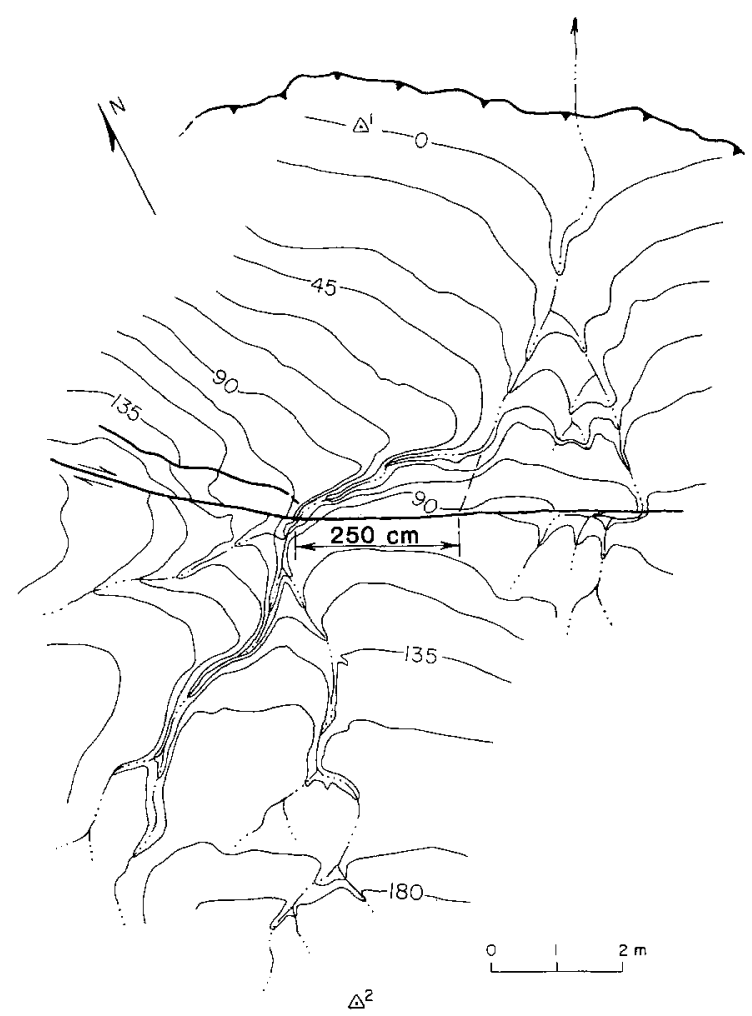

Fig. 5. Contour map of offset rill at site 23a. Contour interval is $15 \mathrm{~cm}$. Linear portion of rill was projected into the fault in order to measure the offset of $250 \pm 45 \mathrm{~cm}$. A small triplet of rills to the right of the $250 \mathrm{~cm}$ multiple offset has recorded both a $120 \mathrm{~cm}$ offset and a $60 \pm 4 \mathrm{~cm}$ offset from the 1987 earthquake. Triangular symbols on this and other contour maps represent benchmarks used for surveying. 
Site $23 a$

A stream channel offset $250 \pm 45 \mathrm{~cm}$ is located $6.75 \mathrm{~km}$ from the northwest end of the Superstition Hills fault. The channel drains a northeast-facing hillside of moderate to steep relief, which enabled the channel to develop a linear trend perpendicular to the fault. Tributary rills on the southwest side of the fault coalesce into a single channel that is offset about $250 \mathrm{~cm}$ by the fault (Fig. 5). The $250 \mathrm{~cm}$ dextral offset was produced by one principal fault strand. A minor thrust fault downstream from this offset produced only 1 to $2 \mathrm{~cm}$ of dip slip in 1987 . The 1987 slip measured in April at the site was $60 \pm 4 \mathrm{~cm}$. The $250 \mathrm{~cm}$ offset is roughly four times larger than the slip at this site associated with the 1987 earthquake.

Another offset rill at same site exhibits a dextral displacement of $120 \mathrm{~cm}$, about twice the amount of slip experienced in 1987 . This can be seen on the northwesternmost rill in a triplet of rills to the southeast of the larger offset (Fig. 5).

\section{Site $24 a$}

A very linear stream channel offset $146 \pm 20 \mathrm{~cm}$ is located approximately $20 \mathrm{~m}$ southeast of site 23a. The channel at site $24 \mathrm{a}$ is oriented perpendicular to the fault and is fed by a number of incised tributaries on a northwest-facing hillside that converge into a single channel approximately $1 \mathrm{~m}$ upstream from the fault (Figs. 3 and 6). The stippled pattern in Figure 6 represents a strath terrace that probably formed after the November 1987 earthquake. In the postearthquake rains the

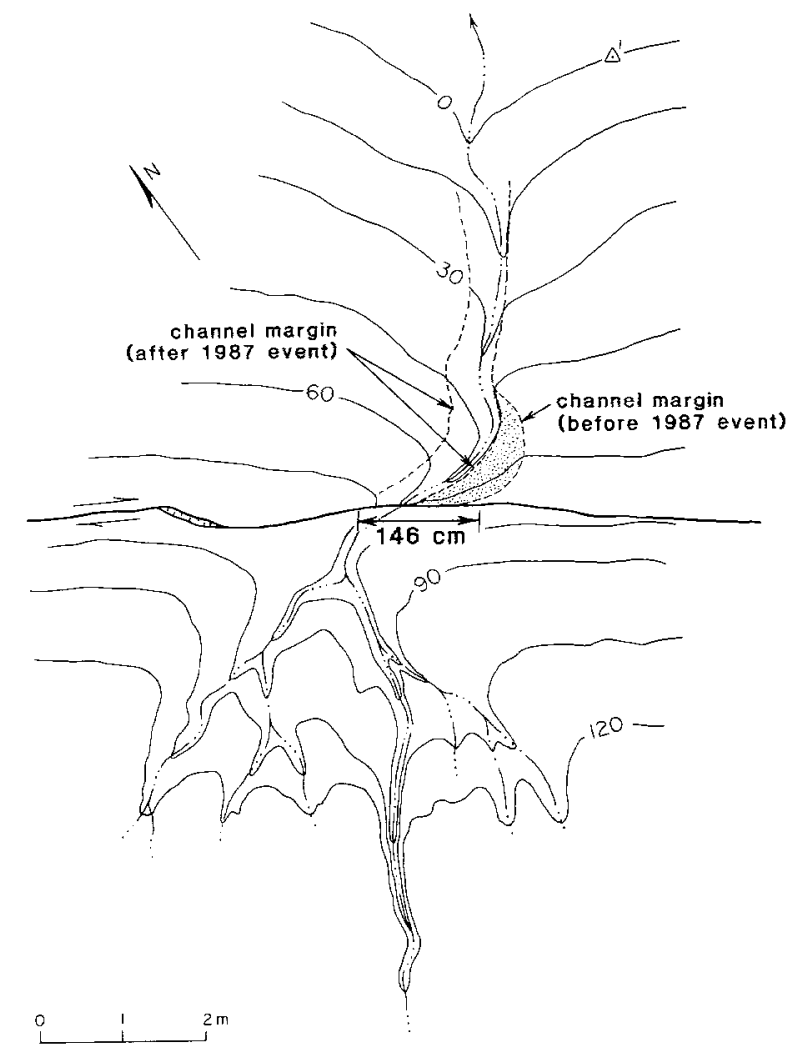

$\Delta^{2}$

FIG. 6. Contour map of offset rill at site $24 \mathrm{a}$. The incised rill is right-laterally offset $146 \pm 20 \mathrm{~cm}$. Contour interval is $15 \mathrm{~cm}$. Downstream from the fault, a strath terrace (stippled area) apparently formed during postearthquake rains as a result of the right-lateral displacement from the 1987 event. 
channel center apparently shifted from the southeast margin of the channel to its present incised position, attempting to straighten its course, leaving behind the flat terrace.

This shift in the thalweg of the channel is roughly equivalent to the $61 \pm 3 \mathrm{~cm}$ displacement of November 1987 recorded on a rill less than $10 \mathrm{~m}$ from site $24 \mathrm{a}$. The $146 \pm 20 \mathrm{~cm}$ right-lateral offset represents the distance obtained by projecting a best-fit line of the linear upstream and downstream portions of the channel center into the fault. The channel at site 24 a has been offset by more than one event; the $146 \mathrm{~cm}$ offset is between two and three times larger than the displacement that occurred from the 1987 earthquake.

\section{Site 42}

Two shrub-coppice dunes, located $7.5 \mathrm{~km}$ from the northwest end of the 1987 rupture, are offset by the fault. Along this reach of the fault, the 1987 rupture was confined to a single, linear strand that displaced both dunes. A well-defined dune with distinct margins was laterally displaced during the 1987 earthquake. Displacement of this feature as of April 1988 was measured as $70 \pm 5 \mathrm{~cm}$ (Fig. 7). Another dune is offset $140 \pm 20 \mathrm{~cm}$, which is twice that of the dune displaced by only the 1987. earthquake (Fig. 7).

This presumably older dune is lower in topographic relief, larger in extent, and more diffuse around its perimeter than the younger, more morphologically distinct dune that is offset $70 \mathrm{~cm}$. This difference in dune morphology is apparently a function of the plants about which the dunes are centered. Only the sparse, dead remains of a bush are present in the $140 \mathrm{~cm}$ offset dune that is now apparently being degraded. On the other hand, a living bush serves as the locus of active deposition of aeolian sand that comprises the $70 \mathrm{~cm}$ offset dune.

\section{Site 39}

Site 39 is located approximately $9 \mathrm{~km}$ from the northwest terminus of the fault on a gentle north-facing slope. The site consists of two small, shallow rills that have been offset by the fault (Fig. 8). Slip that occurred in 1987 has offset and beheaded

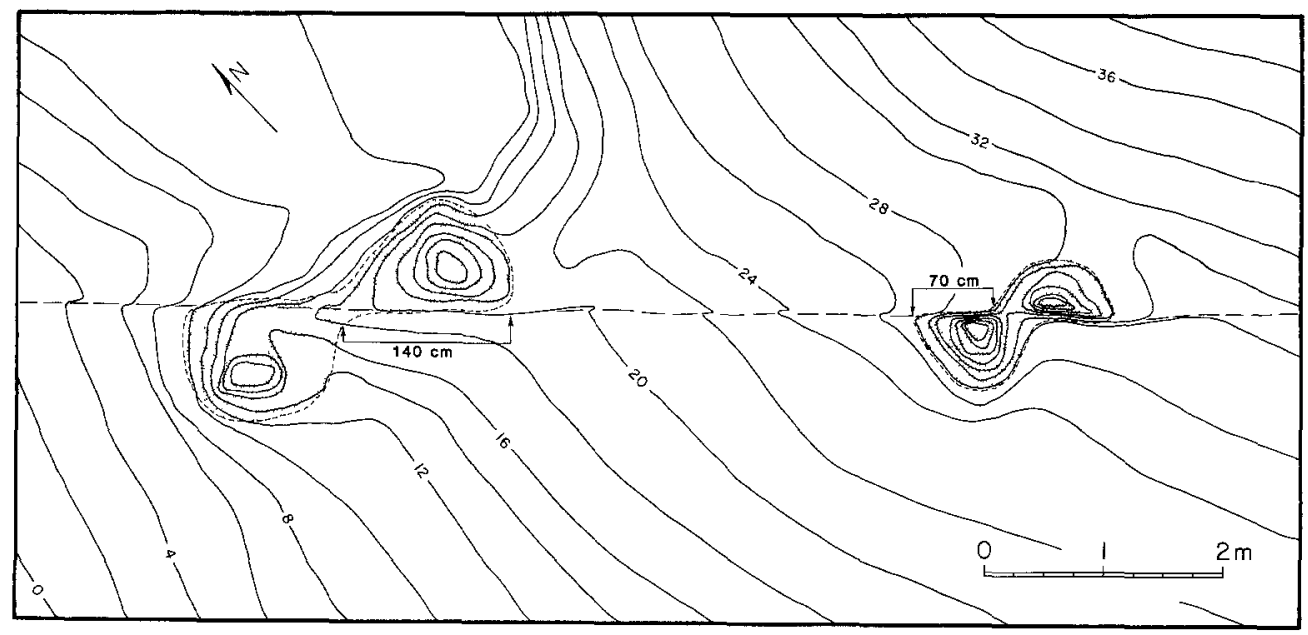

FIG. 7. Contour map of two shrub-coppice bush dunes (stippled areas) offset by the Superstition Hills fault (long-dashed line). Contour interval is $2 \mathrm{~cm}$. The dune on the right was offset $70 \pm 5 \mathrm{~cm}$ in the 1987 rupture event. The total offset of the dune on the left was measured as $140 \pm 20 \mathrm{~cm}$ using the dune margins (short-dashed lines) as piercing points. 


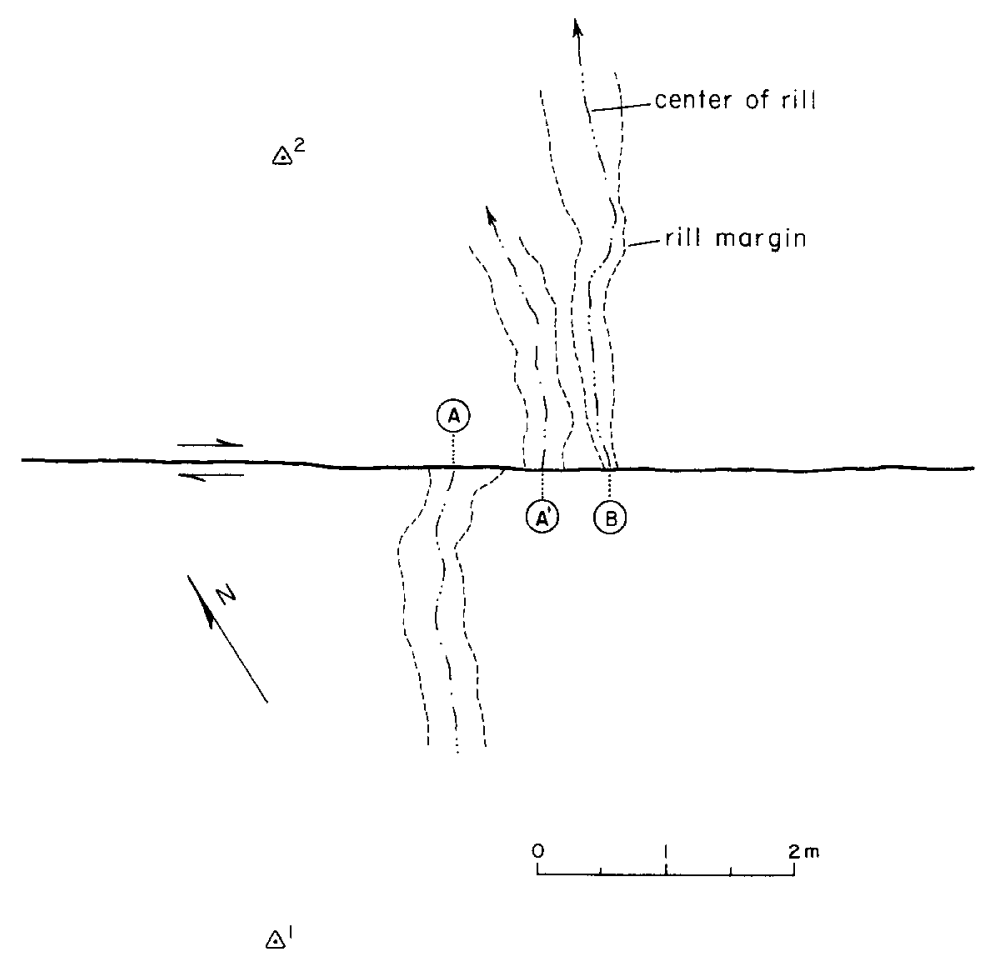

FIG. 8. Line drawing of beheaded rill at site 39. Positions of fault, rill centers, and rill margins were located with a surveying instrument. Offset $A-A^{\prime}$ is $67 \pm 5 \mathrm{~cm}$ from the 1987 event. Offset $A-B$ is $119 \pm$ $10 \mathrm{~cm}$ and is interpreted as cumulative slip from the 1987 event and the penultimate event.

the active rill by $67 \pm 5 \mathrm{~cm}$ (offset $\mathrm{A}-\mathrm{A}^{\prime}$ in Fig. 8). An older, more degraded rill appears to have been beheaded by the penultimate event and is now offset $119 \pm$ $10 \mathrm{~cm}$ (offset B-A in Fig. 8). The north-facing aspect of the slope, along with the north-northeast trend of the rills apparently allowed for complete abandonment of the downslope reach of the rills after each earthquake.

\section{Site 38}

Located approximately $10 \mathrm{~km}$ from the northwest terminus of the fault, this site contains a channel with an apparent offset of $140 \pm 20 \mathrm{~cm}$ across two strands of the fault. The amount of 1987 offset near this location was about $75 \mathrm{~cm}$, about half of that recorded in the offset channel. The map of site 38 (Fig. 9) was contoured by computer at a contour interval of $5 \mathrm{~cm}$. Figure 9 a represents the topography after the 1987 earthquake. The small closed depression immediately upstream from the principal strand of the fault formed in response to a newly created shutter ridge and downdropping of the fault-bounded silver. The absence of abrupt offsets of contour lines at the fault is an artifact of the computer contouring. In Figure 9b, the map was cut and restored along the principal linear strand to reconstruct the original position of the small drainage. The best fit or reconstructed topography indicates a cumulative offset of $140 \pm 20 \mathrm{~cm}$.

\section{Site $W W$}

At this site, located $11.7 \mathrm{~km}$ southeast of the northwest end of the Superstition Hills fault, two small drainages that converge downstream of the fault appear to be offset approximately $140 \mathrm{~cm}$ (Fig. 10a). The offset of the southern drainage was measured between point A on Figure 10a (the intersection of the upstream channel 

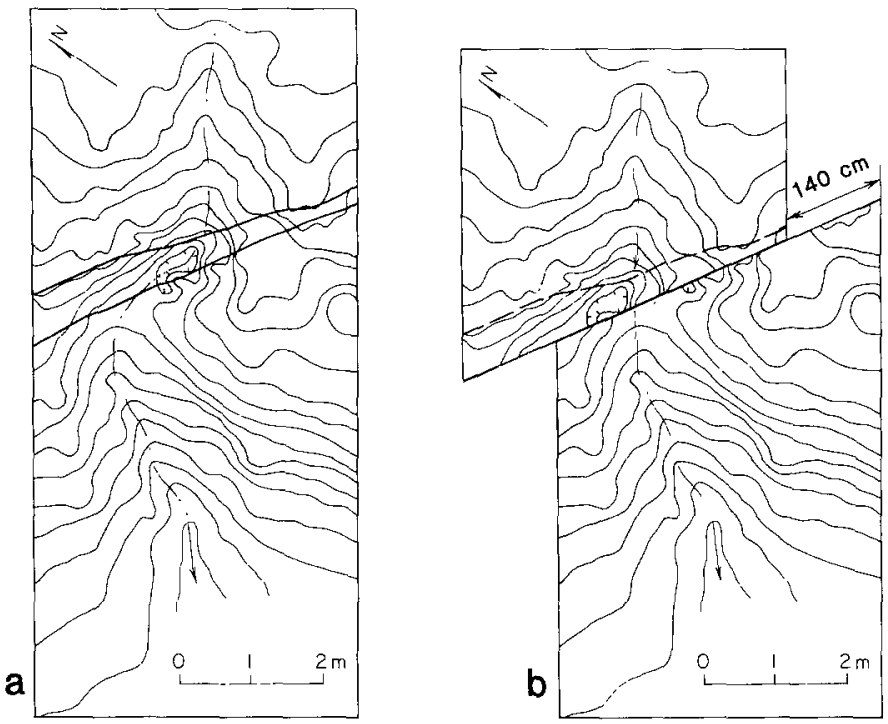

FIG. 9. a) Computer-generated contour map of the $140 \pm 20 \mathrm{~cm}$ offset rill at site 38 . Contour interval is $5 \mathrm{~cm}$. b) $140 \mathrm{~cm}$ restoration of the offset rill along the linear, principal (southwestern) fault strand.
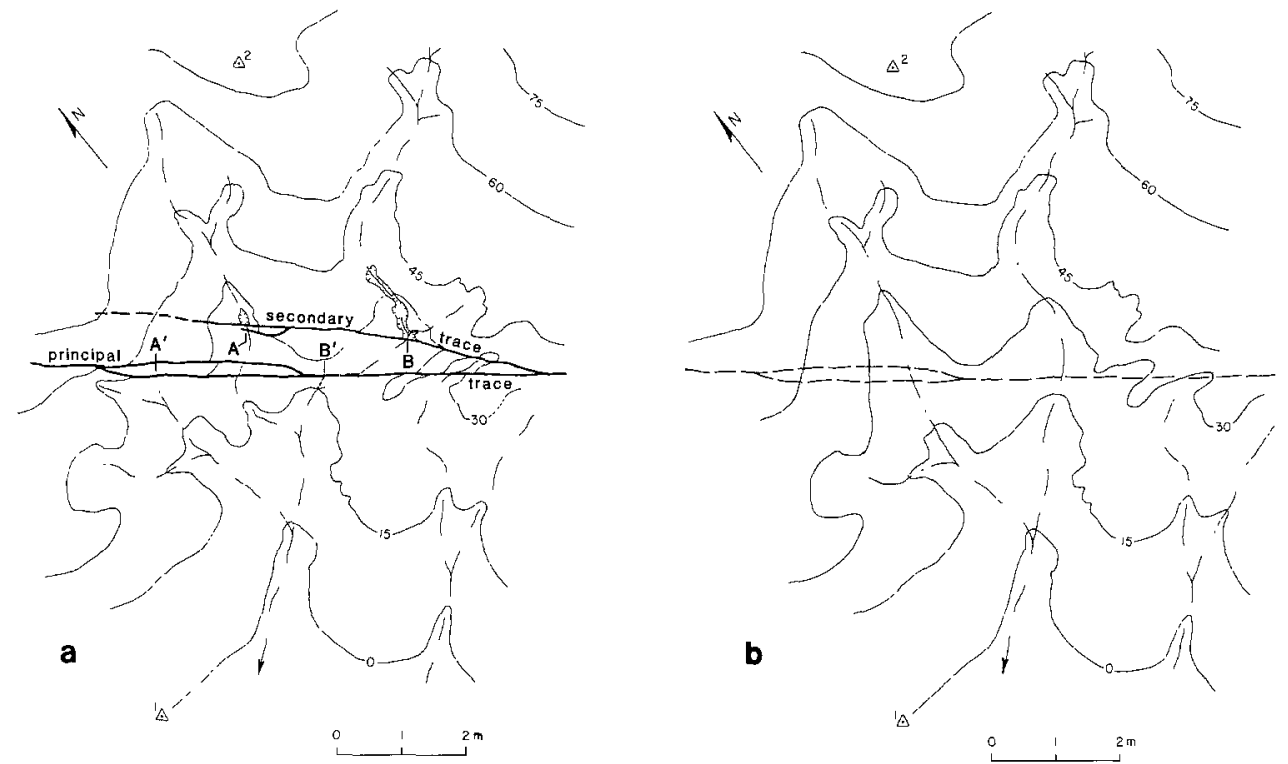

FIG. 10. a) Contour map of two offset rills at site WW. Contour interval is $15 \mathrm{~cm}$. The rill on the left is offset $137 \pm 20 \mathrm{~cm}\left(\mathrm{~A}-\mathrm{A}^{\prime}\right)$ and was judged as fair quality, whereas the rill on the right is offset $140 \pm$ $25 \mathrm{~cm}\left(\mathrm{~B}_{-} \mathrm{B}^{\prime}\right)$ and was judged as good/fair quality (center of rill at $\mathrm{B}^{\prime}$ required minor straightening). b) Reconstructed topography of site WW before the penultimate event. Map was restored $140 \mathrm{~cm}$ along the principal strand of the fault (long-dashed lines) and required only minimal modification of contour lines.

center and the secondary (northeastern) fault strand) and point $\mathrm{A}^{\prime}$ (the intersection of the projected downstream channel center and the principal fault strand) as 140 $\pm 25 \mathrm{~cm}$. Another offset channel was measured between point B in Figure 10a (the intersection of the center of its channel with the secondary (northeastern) fault) and point $\mathrm{B}^{\prime}$ (the intersection of the beheaded channel and the principal fault strand) as $137 \pm 20 \mathrm{~cm}$.

Figure 10b shows the reconstructed topography of site WW after back-slipping the fault $140 \mathrm{~cm}$ and restoring the contours. The nearest measurement of $1987 \mathrm{slip}$, taken approximately $200 \mathrm{~m}$ southeast of site $\mathrm{WW}$, was $70 \pm 2 \mathrm{~cm}$, approximately half of that suggested by the two offset channels. 
Site 7

About $1 \mathrm{~km}$ northwest of where the Naval Range Road bends sharply to the west away from the fault (Fig. 4), a channel is apparently beheaded from the active channel upstream from the fault. These channels are separated by $200 \pm 30 \mathrm{~cm}$ (Figs. 2 and 11). This site is located at a large bend in the fault that has resulted in the downdropping of the northeastern block and the formation of a prominent northeast-facing slope that contains several multiply offset gullies and channels oriented perpendicular to the fault. Site 7 contains two fault strands that slipped in 1987 with the easternmost or principal strand accommodating the majority of offset. The 1987 dextral slip summed across both strands at this site is $68 \pm 5 \mathrm{~cm}$. Displacement on the western strand was predominantly dip-slip, with as much as $12 \mathrm{~cm}$ of normal slip in the southern part of the computer-contoured map. The dipslip component decreased to the north where the 2 strands become closely spaced and parallel. The $200 \pm 30 \mathrm{~cm}$ apparent offset of the beheaded channel is larger than the 1987 slip by a factor of 3 .

Site 21

About $16 \mathrm{~km}$ from the northwest end of the fault and approximately $2 \mathrm{~km}$ northwest of the Naval Range Tower at Imler Road, a single stream has apparent offsets of $120 \pm 10 \mathrm{~cm}$ and $240 \pm 20 \mathrm{~cm}$ (Fig. 12). This broad, flat-bottomed channel flows northeast at a low gradient in an area of very little topographic relief. The well-defined northern channel wall, which was used as the piercing point, is clearly offset $120 \pm 10 \mathrm{~cm}$ with only very little rounding of the channel wall. This offset, which was recorded as of good quality, is similar to the total offset (through March 1988) obtained by Hudnut and Sieh (1989) for cumulative slip from both the 1987 and penultimate events at the Imler Road trench site, $2 \mathrm{~km}$ to the southeast.

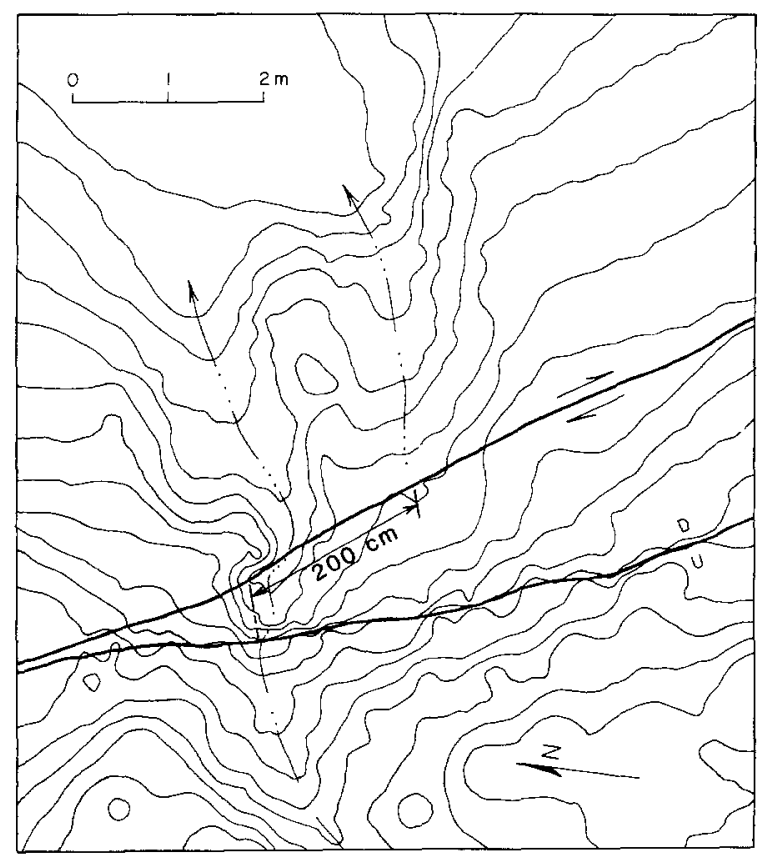

FIG. 11. Computer-generated contour map of the small beheaded stream at site 7. Contour interval is $5 \mathrm{~cm}$. The offset of the beheaded channel is $200 \pm 30 \mathrm{~cm}$. Displacement of the active channel from the 1987 earthquake measured across both strands is $68 \pm 5 \mathrm{~cm}$. 


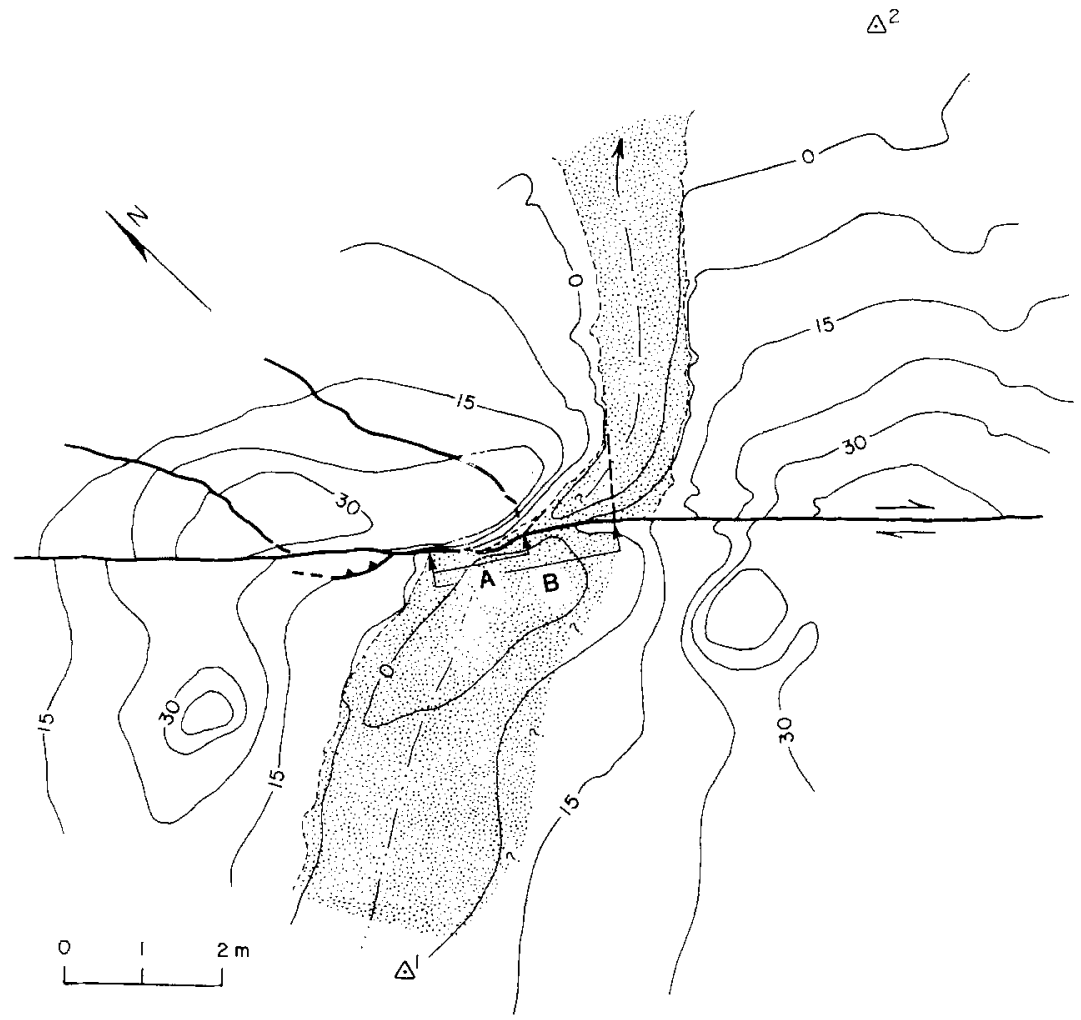

Fig. 12. Contour map of the offset stream at site 21. Contour interval is $7.5 \mathrm{~cm}$. Stippled pattern represents the sand-covered channel bottom and short-dashed lines represent the base of the channel walls. Offsets $A$ and $B$ are $120 \pm 10 \mathrm{~cm}$ and $240 \pm 20 \mathrm{~cm}$, respectively.

A portion of the northern channel wall is significantly rounded immediately downstream from the fault. Straightening of the downstream linear reach into the fault suggests $240 \pm 20 \mathrm{~cm}$ of dextral offset. We feel that this is valid because the channel walls are linear both upstream and downstream from the fault (Fig. 12). Based on these observations, we classified this offset as of good quality. With 1987 slip values near site 21 ranging from 52 to $58 \mathrm{~cm}$, the two offsets of about 120 and $240 \mathrm{~cm}$ are greater than the $1987 \mathrm{slip}$ by factors of about 2 and 4 , respectively.

\section{Discussion}

The repeated offsets interpreted at sites along the 1987 surface rupture indicate that several prehistoric surface faulting events have occurred on the Superstition Hills fault. A few poor-quality offset values are five to six times greater than the amount of 1987 displacement, which may suggest that as many as a half dozen earthquakes can be recognized by study of offset geomorphic features along the Superstition Hills fault. In the following analysis, we assume that the full amount of lateral deflection and apparent offset expressed by each multiply offset geomorphic feature is of tectonic origin, and that we can use these values as accurate estimates of lateral slip within the stated uncertainties.

Nearly 40 per cent of the multiply offset geomorphic features are either exactly or approximately double that of the 1987 slip distribution (as measured in April 1988), suggesting a penultimate slip event with a similar slip distribution to that of 1987. This is consistent with Hudnut and Sieh's (1989) recognition of a prior slip event at their Imler Road site, which they argue was caused by an earthquake. 


\section{Characteristic Earthquake Model}

Probabilistic analysis of earthquake hazards (Sykes and Nishenko, 1984; Wesnousky, 1986) relies, in part, on use of the characteristic earthquake model for recurrence (Schwartz and Coppersmith, 1984). Observations that either support or provide evidence of alternative types of fault behavior have both scientific and societal repercussions; therefore, it is of general interest to test this model against geologic observations. The Superstition Hills fault presents an opportunity to evaluate the characteristic earthquake model in a nearly ideal situation, in which ruptures overlapping along strike can perhaps safely be assumed not to occur (at least to the northwest). We take this opportunity to test the model for this fault to the extent allowed by our data. We also note that an independent test by Hudnut and Sieh (1989) challenges the characteristic earthquake model for this fault. Their results, discussed below, are based on study and evaluation of slip at a single site near the intersection of the Superstition Hills fault with Imler Road.

\section{Testing the Model}

We set up the characteristic earthquake model in its strict sense, that slip per event at any given point along the fault will not vary. Thus, we take as the predicted values the $1987 \mathrm{slip}$ and afterslip through April 1988 (Fig. 13) multiplied by factors of 2,3, and so on (Fig. 14). As observations, we take the values we obtained for total slip across multiply offset geomorphic features. This is illustrated on Figure 14, where integer multiples of the 1987 slip curve of Figure 13 are shown as dotted lines, and the multiple offsets are shown as open circles with error bars.

We then analyze the fit of our observations to curves predicted by the model. For each site, we subtracted integer multiples of $1987 \mathrm{slip}$ from the total slip across

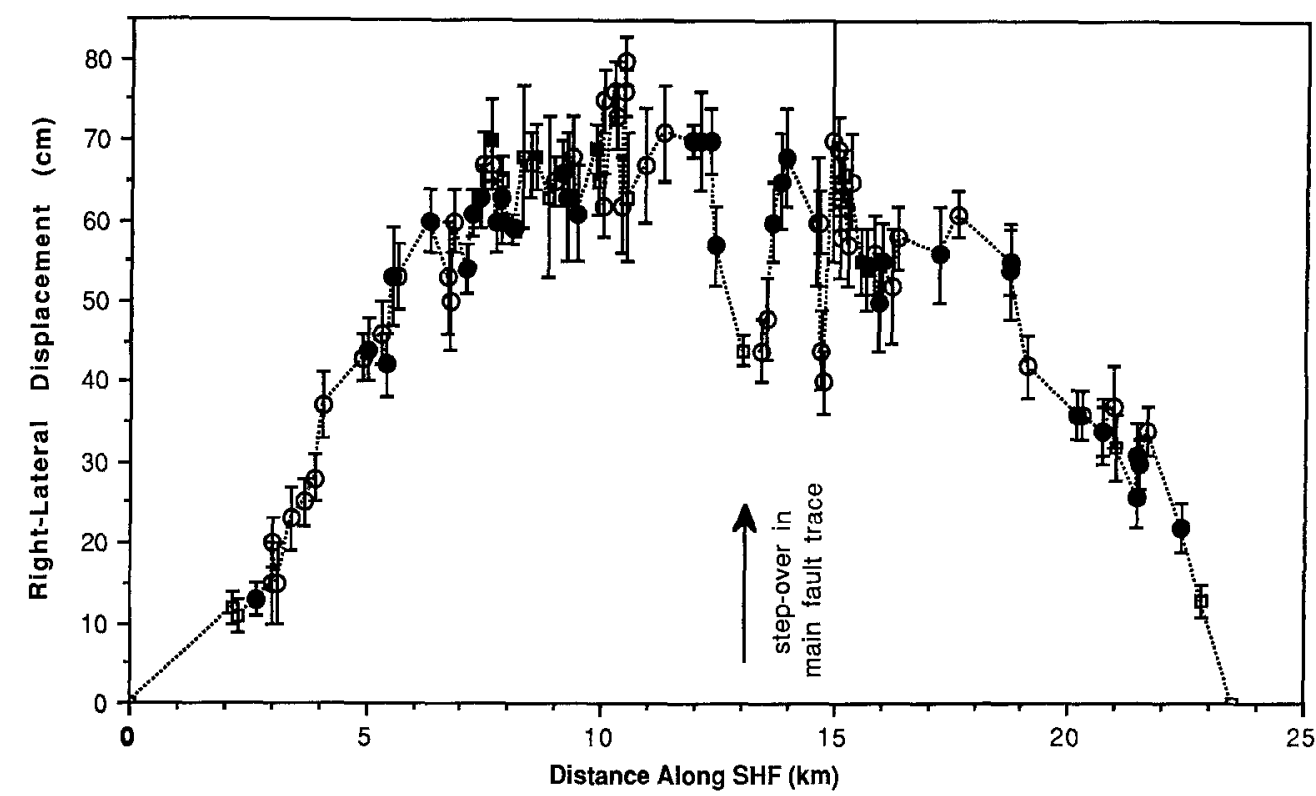

FIG. 13. Slip distribution along the Superstition Hills fault as of April 1988. This curve is defined mainly by data from features comparable to those used to measure pre-1987 offsets. Such features are rills, shown as open circles, and channel walls, shown as filled circles. These two categories comprise about 90 per cent of the data presented on this graph. In addition, offset dunes, lines of grass, and other shorter-lived geomorphic features are grouped as filled square symbols, and transient features such as pull-aparts, tire tracks, and road berms are grouped as open square symbols. Error bars were estimated for each offset in the field. A major stepover in the main trace of the fault is indicated at $13 \mathrm{~km}$ along the fault. This step actually spans from about 12.4 to $13.5 \mathrm{~km}$. 


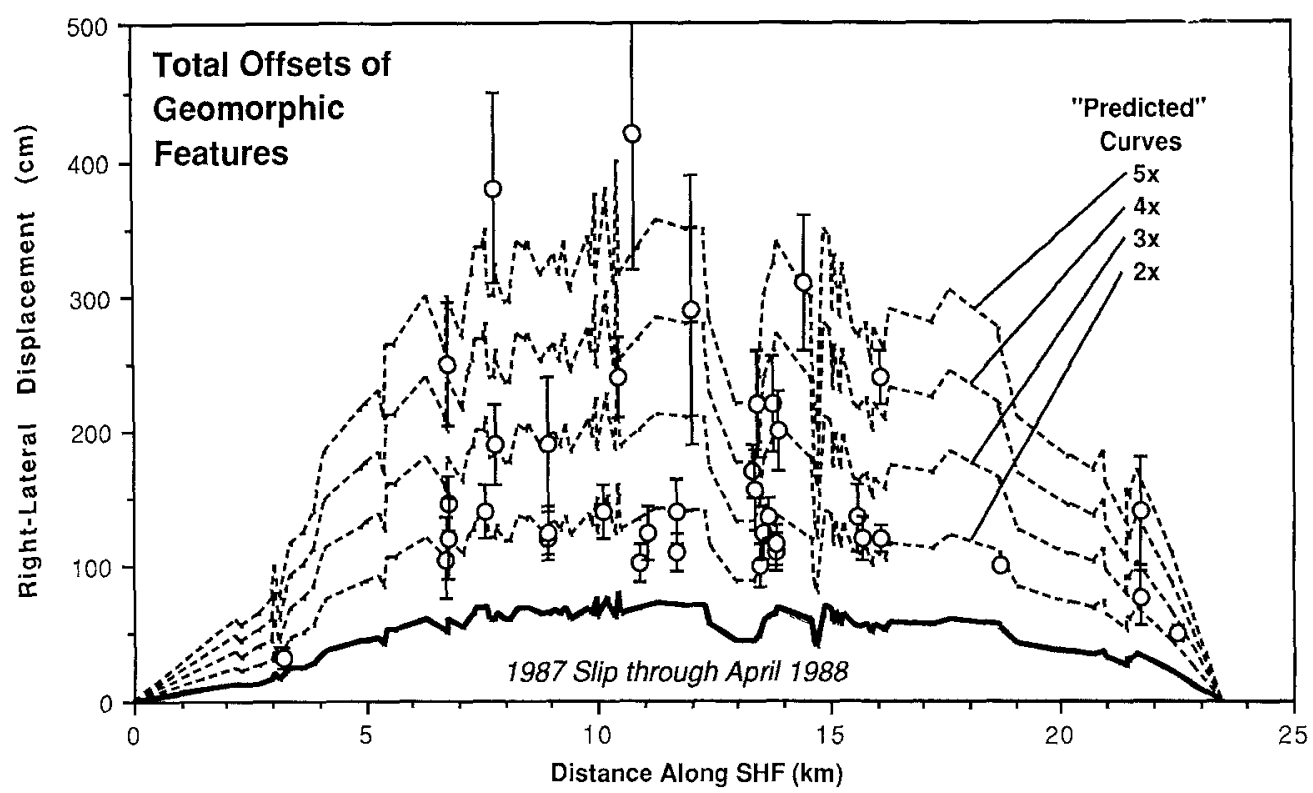

FiG. 14. Illustration of our test of the characteristic earthquake model. The $1987 \mathrm{slip}$ curve presented on Figure 13 has been multiplied by integer factors, producing a family of "predicted" curves. Measurements of offset geomorphic features (open circles with error bars) from Table 1 are overlain upon this family of curves. If these data points fit any of the predicted curves, it suggests the model is correct. Because it is difficult to quantitatively analyze this simply by looking at this graph, we have computed residuals between observed and predicted values on Figure 15.

multiply offset features. For example, we first tested for a single event prior to 1987. The 1987 slip was multiplied by a factor of 2 , generating a set of predicted values. These values were then subtracted from the observed total offsets across features at the same location. This produced the set of residual values shown in Figure 15.

\section{Analysis of the Residuals}

The test for a pre-1987 slip event identical to the 1987 event produces a strong concentration of residuals about the zero value, supporting the characteristic earthquake hypothesis for the penultimate event. These residuals are not normally distributed; instead there appears to be a weak second mode in the data centered about $+70 \mathrm{~cm}$. This may be expected because we mix values from the penultimate event with older events. The weak second mode centered at about $+70 \mathrm{~cm}$ may reflect an event before the penultimate earthquake.

Because we multiplied the 1987 slip distribution strictly, minor variations in 1987 slip were amplified in the test for the residuals. This may have had the effect of scattering the residual plot to some degree. Alternatively, it may reflect real variability in slip per event at a given point along the fault.

The data are too sparse to conclusively test the characteristic earthquake hypothesis for any slip events earlier than the penultimate event. The suggestion of a prepenultimate event seems strong from the mode of residuals near $+70 \mathrm{~cm}$ (Fig. 15 ). When the appropriate test (total slip $-1987 \operatorname{slip} \times 3$ ) for this event was made, however, the apparent concentration broadened, so we are not confident that a characteristic prepenultimate earthquake is represented in the data.

Visual inspection of the distribution of the residuals should be sufficient to support the conclusion that one pre-1987 event did produce slip along the Superstition Hills fault that was very comparable to the slip in November 1987 and its related afterslip through April 1988. 


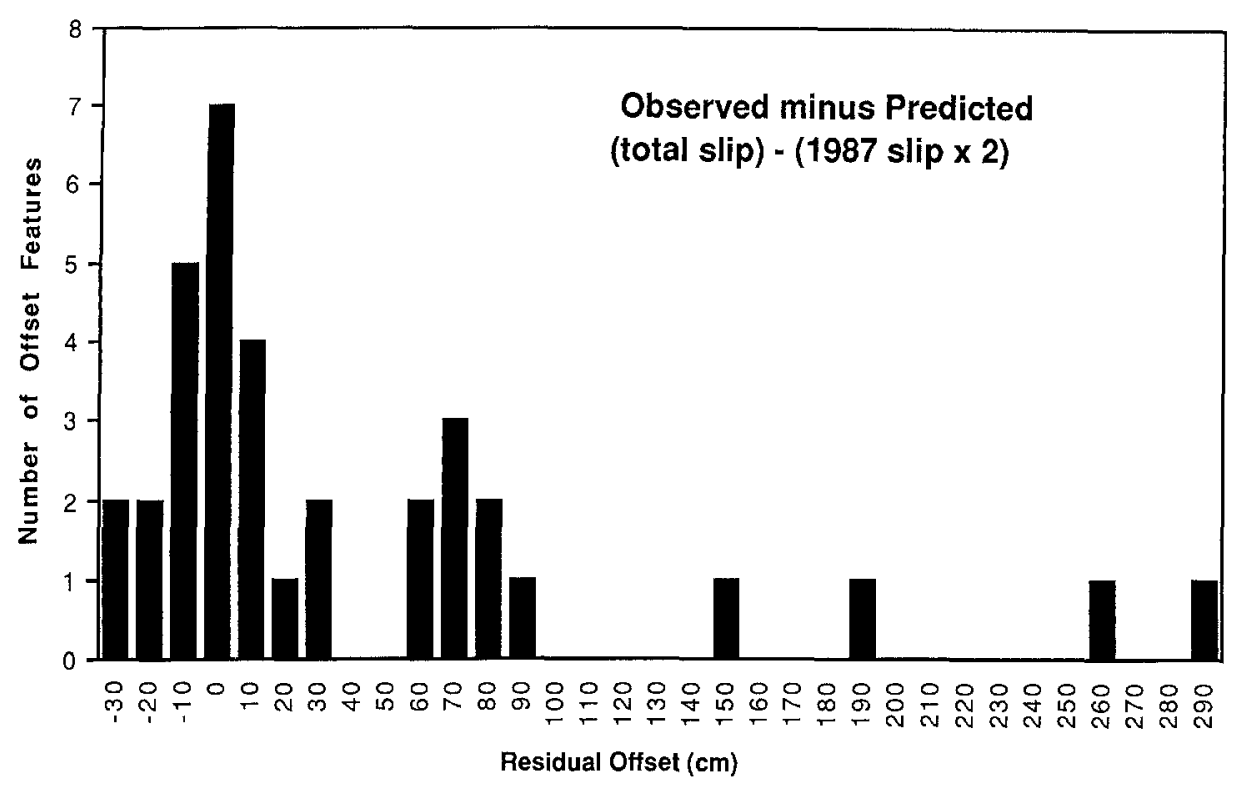

FIG. 15. Distributions of residuals between observed and predicted values for multiple offsets along the Superstition Hills fault. When predicted values for one pre-1987 event were subtracted from the total offsets, this plot of residuals resulted. It shows a strong concentration about the zero value, which would be expected if the model is correct. Also, a weak secondary mode is seen at about $+70 \mathrm{~cm}$, possibly indicating a prepenultimate event.

\section{Consideration of the Imler Road Results}

Although this analysis indicates a close correlation between co-seismic and afterslip of the 1987 event to total slip in the previous event, this does not completely resolve our test of whether the characteristic earthquake model is appropriate for this fault. Because afterslip continues to accumulate along most of the length of the Superstition Hills fault trace as of mid-1988, its long-term effects must be considered.

Hudnut and Sieh (1989) have established at their Imler Road excavations that total postlake slip before the 1987 event was about $60 \mathrm{~cm}$. Total slip from the 1987 rupture plus afterslip, measured at about $50 \mathrm{~cm}$ in March 1988, will not reach 60 $\mathrm{cm}$ until about March 1989. Nonetheless, their extrapolation of aftercreep data 150 to $300 \mathrm{yrs}$ into the future (one estimated recurrence interval) predicts that total slip from the 1987 rupture will reach about $120 \mathrm{~cm}$ at Imler Road. The implication of their result also applies to our test of whether the characteristic earthquake model is applicable to the Superstition Hills fault. If we assume that afterslip along the entire trace of the Superstition Hills fault will continue to accumulate in the future, then the close similarity we observe between 1987 slip (through April 1988) and the penultimate event slip may be fortuitous. Williams and Magistrale (1989) show abundant afterslip data suggesting that nearly the entire length of the fault can be expected to continue to creep, and that eventual slip accumulation along the fault may significantly increase the values obtained in April 1988, with maximum slip values along the central reach of the fault increasing to about $120 \mathrm{~cm}$. Therefore, the same argument made by Hudnut and Sieh for their data at Imler Road likewise applies to our analysis, in that eventual total slip from the 1987 event may be significantly larger than that of the penultimate event.

The fault may continue to creep at our locations showing the multiple offsets. Although a strong correspondence exists between the April 1988 values and the 
penultimate event slip values, this will be changed. The expected outcome would be that slip distribution along the entire fault caused by the 1987 event would be greater than the amounts caused at the same sites by the penultimate event. A rigorous evaluation of this effect will require consideration of afterslip data at locations documented in other studies in this issue. On our plot of residuals, however, a simple shift towards the left, and perhaps changes in the distributions of residuals, would be the anticipated changes.

If this occurs, the characteristic earthquake model is not applicable to this fault in a strict sense for its most recent behavior. It would support the hypothesis by Hudnut and Sieh (1989) that the 1987 event was larger than the previous event. Alternatively, Boatwright et al. (1989) used a damped power law for projection of afterslip into the future which suggests that most afterslip (greater than 95 per cent) will have occurred within the first few years after the earthquake. Their projected values are considerably less $(<1 \mathrm{~m})$ and suggest that the slip we measured from the 1987 earthquake (through April 1988) is not significantly different than the projected total slip for this event.

Our data provide constraints that Hudnut and Sieh (1989) could not address regarding variation in slip along strike and length of the penultimate rupture. We have shown that slip distribution as of April 1988 was similar to that in the penultimate event along the central portion of the fault. The length of the pre-1987 rupture is not well constrained by this study, but it is evident that at least the reach of the fault from about 6 to $16 \mathrm{~km}$ from the northwest end has experienced slip before the 1987 earthquake.

\section{Triggered Slip}

The historical occurrence of triggered slip on the Superstition Hills fault (Allen et al., 1972; Fuis, 1982; Sharp et al., 1986) was not included in our analysis. The total amount of triggered slip of nearly $4 \mathrm{~cm}$ (Sharp et al., 1986) since the 1968 Borrego Mountain earthquake could easily be absorbed in the errors of our offset measurements and, therefore, would not alter our interpretations. If the features we observed were offset by a large accumulation of creep, we could not necessarily distinguish this from co-seismic offset. Hudnut and Sieh (1989) have argued for seismic slip in the penultimate event. Our observations suggest slip before the penultimate event, but we cannot say what percentage of this slip was seismic.

\section{CONCLUSIONS}

Documentation of offset geomorphic features along the Superstition Hills fault have helped constrain the slip distribution of one rupture event that occurred before the 1987 earthquake. Older and larger offsets less clearly show evidence for several other prehistoric events.

Along reaches of the fault where we have data, it appears that the penultimate event had a slip distribution similar to the 1987 total slip distribution as measured through April 1988. If afterslip on the Superstition Hills fault is arrested in the near future, our data will support the application of the characteristic earthquake model to this fault. However, if slip continues to accrue for the next 150 to $300 \mathrm{yrs}$ until the next earthquake, as suggested by some workers, then afterslip is expected to increase the 1987 total slip to approximately twice that of the penultimate event. If this occurs, then either characteristic earthquakes exhibit a large degree of variability near their maximum magnitudes, or the model is not applicable to the Superstition Hills fault. 
Continued monitoring of the 1987 event's afterslip will determine if total slip from this earthquake will stabilize or continue to increase with time. This will enable more accurate estimates of the size of past earthquakes on the Superstition Hills fault as well as provide checks on this test of the characteristic earthquake model for this fault.

\section{ACKNOWLEDGMENTS}

We are grateful to $R$. Wallace for his initial enthusiasm to pursue this study of the offset features along this fault. We thank D. Valentine at SDSU for helping with the surveying, T. Hanks at the USGS for providing us with new air photos, and P. Williams at L-DGO/C.I.T. for his discussions on afterslip. We especially thank D. Schwartz for his thoughtful review of our manuscript, which led to improvements and clarification of the presentation. This project was partially supported by USGS Grant no. 14-080001-G1330.

\section{REFERENCES}

Allen, C. R., M. Wyss, J. N. Brune, A. Grantz, and R. E. Wallace (1972). Displacements of the Imperial, Superstition Hills, and San Andreas faults triggered by the Borrego Mountain earthquake, in The Borrego Mountain earthquake of April 9, 1968, U.S. Geol. Surv. Profess. Paper 787, 87-104.

Boatwright, J., K. E. Budding, and R. V. Sharp (1989). Inverting measurements of surface slip on the Superstition Hills fault, Bull. Seism. Soc. Am. 79, 411-423.

Clark, M. M. (1972). Surface rupture along the Coyote Creek fault, in The Borrego Mountain earthquake of April 9, 1969, U.S. Geol. Surv. Profess. Paper 787, 55-86.

Fuis, G. (1982). Displacement on the Superstition Hills fault triggered by the 1979 Imperial Valley earthquake, in The Imperial Valley earthquake of October 15, 1979, U.S. Geol. Surv. Profess. Paper $1254,145-154$.

Hudnut, K., L. Seeber, T. Rockwell, J. Goodmacher, R. Klinger, S. Lindvall, and R. McElwain (1989). Surface ruptures on cross-faults in the 24 November 1987 Superstition Hills, California, earthquake sequence, Bull. Seism. Soc. Am. 79, 282-296.

Hudnut, K. and K. Sieh (1989). Behavior of the Superstition Hills fault during the past 330 years, Bull. Seism. Soc. Am. 79, 304-329.

Kahle, J. E., C. J. Wills, E. W. Hart, J. A. Treiman, R. B. Greenwood, and R. S. Kaumeyer (1988). Preliminary report: surface rupture-Superstition Hills earthquakes of November 23 and 24, 1987, California Geology 41, 75-84.

Rockwell, T. K. and C. T. Pinault (1986). Holocene slip events of the southern Elsinore fault, Coyote Mountains, southern California, in Neotectonics and Faulting in Southern California: Geological Society of American Guidebook for the Cord. Sect. Meeting in Los Angeles, 193-196.

Schwartz, D. P. and K. J. Coppersmith (1984). Fault behavior and characteristic earthquakes: examples from the Wasatch and San Andreas fault zones, J. Geophys. Res. 89, 5681-5698.

Sharp, R. V., K. E. Budding, J, Boatwright, M. J. Ader, M. G. Ader, M. G. Bonilla, M. M. Clark, T. E. Fumal, K. K. Harms, J. J. Lienkaemper, D. M. Horton, B. J. O'Neill, C. L. Ostergren, D. J. Ponti, M. J. Rymer, J. L. Saxton, and J. D. Sims (1989). Surface Faulting along the Superstition Hills fault zone and nearby faults associated with the earthquakes of 24 November 1987, Bull. Seism. Soc. Am. 79, 252-281.

Sharp, R. V., M. Rymer, and J. Lienkamper (1986). Surface displacement on the Imperial and Superstition Hills faults triggered by the Westmoreland, California earthquake of 26 April 1981, Bull. Seism. Soc. Am. 76, 949-965.

Sieh, K. E. (1978). Slip along the San Andreas fault associated with the great 1857 earthquake, Bull. Seism. Soc. Am. 68, 1421-1448.

Sieh K. E. (1987). Earthquake geology of the San Andreas and other faults in California: Annual Technical Report, Grant No. 14-08-0001-G1098, submitted to U.S. Geol. Surv., 12 November 1987.

Sieh, K. E. and R. Jahns (1984). Holocene activity of the San Andreas fault at Wallace Creek, California, Geol. Soc. Am. Bull. 95, 883-896.

Sykes, L. R. and S. P. Nishenko (1984). Probabilities of occurrence of large plate rupturing earthquakes for the San Andreas, San Jacinto, and Imperial faults, California, J. Geophys. Res. 89, 5905-5927.

Wallace, R. E. (1968). Notes of stream channels offset by the San Andreas fault, southern Coast Ranges, California, in Proceedings of Conference on Geologic Problems of San Andreas Fault System, Stanford University Publications, Geological Sciences, University Series 11, 6-21.

Wallace, R. E. (1970). Earthquake recurrence intervals on the San Andreas fault, Geol. Soc. Am. Bull. 81, 2875-2890. 
Waters, M. R. (1983). Late Holocene lacustrine chronology and archeology of ancient Lake Cahuilla, California, Quat. Res. 19, 373-387.

Wesnousky, S. G. (1986). Earthquakes, Quaternary faults, and seismic hazards, J. Geophys. Res. 91, $12587-12631$.

Williams, P. L. and H. W. Magistrale (1989). Slip along the Superstition Hills fault associated with the 24 November 1987 Superstition Hills, California, earthquake, Bull. Seism. Soc. Am. 79, 390-410.

Zhang, W., D. Jiao, P. Zhang, P. Molnar, B. C. Burchfiel, Q. Deng, Y. Wang, and F. Song (1987). Displacement along the Haiyuan fault associated with the great 1920 Haiyuan, China, earthquake, Bull. Seism. Soc. Am. 77, 117-131.

Department of Geological SCIEnCes

San Diego State University

San Diego, California 92182

(S.C.L., T.K.R.)

Manuscript received 4 August 1988
LAMONT-DOHERTy GeOLOGICAL ObSERVATORY Palisades, New YoRK 10964 and Department of Geological Sciences COLUMbia UnIVERSity

New YoRK, New YoRK 10027

(K.W.H.) 